\title{
Effects of group size and early handling on some behavioural and physiological welfare parameters in farmed blue foxes
}

Leena Ahola, Mikko Harri, Jaakko Mononen, Teija Pyykönen and Sari Kasanen

Institute of Applied Biotechnology, University of Kuopio, PO Box 1627, FIN-70211 Kuopio, Finland,

e-mail: leena.ahola@uku.fi

\begin{abstract}
The present study included two procedures, both aimed at improving animal welfare: early handling and changing the social conditions of the animals. Production and welfare related parameters as well as behaviour were assessed in blue fox (Alopex lagopus) cubs who were either handled or not before weaning, and housed after weaning either in pairs or in six-animal groups. The effect of the larger group size was observed in the larger number of bite scars in the female cubs housed in six-animal groups. Furthermore, the group size seemed to affect the performance of foxes most clearly in the late autumn when intra-litter aggression was observed during the feeding test. On the other hand, early handling had only short-term positive effects on the performance of the foxes but later transpired to have a negative impact on the stress profile of these animals.
\end{abstract}

Key words: Alopex lagopus, early handling, group size, animal welfare

\section{Introduction}

The public interest in the welfare of production animals has generated many studies aimed at improving the overall welfare of these animals. The most common procedures used to improve animal welfare have been handling of the animals in an attempt to reduce later fear towards humans (Rushen et al. 1999) and changing either the social (Mendl and Newberry 1997) or physical conditions of the animals (Appleby and Waran 1997).
In farmed blue foxes (Alopex lagopus), environmental enrichment has been the most common tool used to potentially enhance the welfare of the animals (resting platforms: Korhonen and Niemelä 1994, Mononen 1996; nest boxes: Pedersen and Jeppesen 1993, Harri et al. 1998, Mononen et al. 1999; gnawing blocks: Korhonen and Niemelä 2000). Less attention has been directed towards the effects of the social conditions in the cage environment (Ahola et al. 1996, Ahola et al. 2000), of the space allowance (Pedersen and Jeppesen 1998, Korhonen et al. 2000) and of early handling. The only results 
Ahola, L. et al. Group housing and early handling in farmed blue foxes

concerning early handling of farmed juvenile foxes are from silver foxes (Pedersen and Jeppesen 1990, Pedersen 1992, 1993).

Housing farmed foxes in social units can provide the animals with more total available space, even though the space per individual animal remains the same. The effects of cage size on the welfare of singly housed blue foxes have been studied in Denmark by Pedersen and Jeppesen (1998) and in Finland by Korhonen et al. (2000). The results from these studies revealed no clear advantages with regard to foxes' welfare with increasing the cage size but did indicate that increasing space induced fearfulness towards humans. Ahola et al. (2000) examined the effects of group housing of blue foxes in a larger cage area. The welfare-related indicators revealed that blue foxes housed in six-animal groups in large cage systems $\left(1.2 \mathrm{~m}^{2}\right.$ per animal, height of the cage $70 \mathrm{~cm}$ ) were, in general, less stressed than foxes housed in pairs in a traditional single cage system $\left(0.6 \mathrm{~m}^{2}\right.$ per animal, height of the cage $70 \mathrm{~cm}$ ). However, no clear conclusion could be drawn whether this was due to the space allocation, the group size or the combination of these two factors. The foxes housed in the larger area were, however, considered to be more fearful towards humans than the foxes housed in the traditional cage system. The authors, therefore, concluded that if blue foxes are to be housed in larger cage systems, the animals should be habituated to humans by early handling procedures. In silver foxes, early handling has been found to reduce foxes' later fear towards humans and this was considered to improve the foxes' welfare (Pedersen and Jeppesen 1990, Pedersen 1992, 1993, 1994).

The aim of the present study was to evaluate the effects of an early handling procedure on the welfare of farmed blue fox cubs housed after weaning either in male-female sibling pairs or in six-animal groups consisting of three male and three female siblings. Furthermore, in contrast to Ahola et al. (2000) who used a larger space allocation for the foxes housed in groups compared to the paired housed foxes, the space per individual animal in the present study was kept equal $\left(0.6 \mathrm{~m}^{2}\right.$ per animal $)$ in both systems in order to assess the effects of space allocation on the welfare related indicators.

\section{Material and methods}

The study was approved by the Institutional Animal Care and Use Committee of the University of Kuopio, Finland (Licence No 99-43).

\section{Animals and housing conditions}

A total of 80 farm born blue fox cubs, born in May-June, were included in this study. During the first eight weeks of their lives, the cubs had experienced either an intensive handling procedure (handled cubs, H) or only the handling required in the normal farming practice (non-handled cubs, NH). The cubs, that were handled intensively (40 cubs) while still in home cage with their mother, were touched gently three times per day during the first eight days and after that once a day until the age of eight weeks, i.e. until the time of weaning. If the cub stepped back from the handler during the handling session, the person drew her hand away from that cub, i.e. no cub was too fiercely handled. In total, each cub was handled 73 times and 11 of these handlings included also a weighing. The cubs under normal farming practice (40 cubs), were weighed once a week from the age of two weeks until the age of eight weeks, i.e. these cubs were handled seven times pre-weaning.

At the time of weaning, the cubs in both groups ( $\mathrm{H}$ and $\mathrm{NH})$ were divided into two experimental groups with regard to the group size, i.e. cubs housed in pairs or in six-animal groups. Thus, four experimental groups were formed: pair housed cubs with early handling $(\mathrm{PH})$, pair housed non-handled cubs (PNH), group housed cubs with early handling $(\mathrm{GH})$ and group housed non-handled cubs (GNH). In the groups $\mathrm{PH}$ and $\mathrm{PNH}$, five male-female sibling pairs were housed 
as pairs in standard fox cages $(115 \times 105 \times 70$ $\mathrm{cm}, \mathrm{L} \times \mathrm{W} \times \mathrm{H})$ furnished with a platform (105 $\times 30 \mathrm{~cm}, \mathrm{~L} \times \mathrm{W}$ ) made of plastic covered wire mesh. In groups GH and GNH, five housing units each consisting of three male and three female siblings were formed. Each sibling group was housed in a three-cage system, where standard fox cages were connected by openings $(20 \times$ $20 \mathrm{~cm}, \mathrm{~W} \times \mathrm{H})$ through the walls between the adjacent cages. All cages were furnished with a platform similar to that used in the pair housed system.

The experimental groups were positioned in a two-row outdoor shed with groups of handled and non-handled animals alternating. The animals were located in the shed so that groups $\mathrm{PH}$ and GH as well as groups PNH and GNH were always situated across from each other on the opposite sides of the aisle of the shed. No empty cages were left between the pair housed cubs but the other cages, if not included in the present study, were inhabited by singly housed foxes not belonging to the present study.

All the foxes were fed with fresh fur animal feed twice a day until late September and once a day thereafter. The feed was delivered on one feeding tray per unit for groups $\mathrm{PH}$ and $\mathrm{PNH}$ and on three feeding trays per unit for groups $\mathrm{GH}$ and GNH.

\section{Measured parameters}

After weaning the cubs were weighed in late August, in late September and at the time of pelting in early December.

The feeding test (Rekilä et al. 1997) was performed in late August, in late September and in late October. Since the animals were not visibly marked on their fur and therefore could not be identified individually without capturing them, the results from the feeding tests are expressed as the percentage of animals in each housing unit eating within the test time. In the test, the experimenter placed feed on the feeding tray, stayed in the front of the cage for $60 \mathrm{sec}$ and recorded the number of individuals coming to eat during the test. The animals in the left and right row of the shed were tested consecutively. For groups $\mathrm{GH}$ and GNH, the feed was delivered on the tray in the middle cage.

The behaviour of the cubs was video-recorded for $24 \mathrm{~h}$ in early September and in late October. The video system consisted of five black and white video cameras (Ikegami CCD Model ICD $30 \mathrm{E}$ ) with wide angle lenses (Cosmicar, $2.8 \mathrm{~mm}$, 1:1.3 CS), a camera switcher (Computar CS8.1), a time-lapse video-recorder (Hitachi VTL2500E) and a black and white monitor (Philips 12TX3512). During the dark hours, a dim red light (Osram, $25 \mathrm{~W}$ ) for two cages and a fluorescent lamp covered with red plastic film for two cages was used in September and in October, respectively. The behaviour of the animals was analysed from videotapes using instantaneous sampling with approximately 250 -sec sampling interval. Each of the five cameras used, thus recorded the behaviour of the animals in one housing unit approximately for 50 -sec providing about 14 sampling points per each housing unit per one hour (Martin and Bateson 1993). The behavioural categories for the cubs were (a) active, i.e. moving, standing or sitting and (b) lying awake or asleep. Since the cubs were not individually identifiable, the activity was expressed as the mean value of siblings' activity in each housing unit (Martin and Bateson 1993). The time spent doing active behaviours was analysed for the three 8 -h periods in the day, i.e. early hours (0000-0800), working hours (0800$1600)$ and evening hours (1600-0000).

Urine was collected for $24 \mathrm{~h}$ in mid October from all the housing units. The samples were stored at $-20^{\circ} \mathrm{C}$ until analysis of cortisol and creatinine. The cortisol concentration (nmol/l) of the urine samples was analysed by a competitive immunoassay technique (Coat-A-Count Cortisol Assay by Diagnostic Products Corporation, Los Angeles, CA). The concentration of creatinine (nmol/l) was analysed at the University Hospital of Kuopio (Finland) by kinetic Jaffe's reaction. Due to the variation in the dilution of urine the content of cortisol in the urine was expressed as the cortisol:creatinine (C:C) 
Ahola, L. et al. Group housing and early handling in farmed blue foxes

ratio (Novak and Drewsen 1989, Lasley and Kirkpatric 1991).

At pelting time in early December, the foxes were caught and injected i.m. with ACTH (0.3 ml Synacthen Depot, synthetic $\mathrm{ACTH}_{1-24}$, Ciba). After the injection, the foxes were placed alone into a smaller cage $(70 \times 35 \times 35 \mathrm{~cm}, \mathrm{~L} \times \mathrm{W} \times$ $\mathrm{H})$, and $2 \mathrm{~h}$ after injection they were euthanized by electrocution and blood samples were drawn with heart puncture. The serum cortisol level (nmol/l), as a maximum response to ACTH administration (Fraser and Broom 1990, Terlouw et al. 1997, Rekilä et al. 1999), was analysed by a competitive immunoassay technique (Coat-ACount Cortisol Assay by Diagnostic Products Corporation, Los Angeles, CA).

After pelting, both adrenals were removed, cleaned and weighed. The number of bite scars in the leather side of the fleshed skins was recorded. The skins were classified according to the number of bite scars into 7 classes (1: no bite scars, 2: 1-5 scars, 3: 6-10 scars, 4: 11-20 scars, 5: over 20 clear scars, 6: high number of scars, 7: extremely high number of scars). Professional fur graders at the Finnish Fur Sales Ltd (Helsinki, Finland) evaluated the quality of the furs using a 10-point scale (1: poorest, 10: best).

\section{Statistical analyses}

Since the individuals within each housing unit were genetically related (i.e. cubs from the same litter) mean values of measured parameters of individuals within each housing unit were used in all analyses (Martin and Bateson 1993). Furthermore, to be able to evaluate whether the dominance hierarchy within groups including both male and female blue foxes (Korhonen and Alasuutari 1994, 1995) had any influence on the measured parameters, mean values for male and female cubs were differentiated. Therefore, the number of cases in each experimental group was five for both males and females.

All the mass parameters as well as parameters describing the activity of the hypothalamicpituitary-adrenal (HPA) -axis, when expressed as mean values of same sex individuals within each housing unit, were normally distributed. Thus, the General Linear Model procedure was used to examine the effects of sex, handling (handled or non-handled) and group size (two or six) on these parameters. The repeated measures MANOVA was used to test for differences in daily activity between the four experimental groups. The results from the feeding tests and from skin grading were not normally distributed and the non-parametric Mann-Whitney test was used to assess the effects of group size and early handling on these parameters. The difference between the months in the feeding test behaviour was analysed within each experimental group with the non-parametric Friedman test. Since there were differences in fur quality between males and females $(P=0.003)$, both sexes were analysed separately for the quality of the fur as well as for the incidence of bite scars.

All the results have been expressed as mean \pm SD. P-values over 0.1 have been considered as non-significant (NS).

\section{Results}

No interaction between sex, early handling and group size was found in any of the measured parameters (for all interactions: NS).

The effect of sex on the body mass of the animals was significant only at the pelting time but a tendency for this was seen already in late September (Table 1). Group size (two or six animals) had no effect on the body mass. In late August the cubs given intensive early handling were heavier than the cubs under normal farming practice without extra handling but this difference disappeared with time.

No sex differences were found in parameters describing the HPA-axis activity (Table 2). No difference between the experimental groups was found in the $\mathrm{C}: \mathrm{C}$ ratio. In the foxes handled during their early life, the adrenals were heavier and the serum cortisol level after ACTH administration was higher than in the foxes without inten- 
Vol. 11 (2002): 25-35.

Table 1. Development of the body mass $(\mathrm{kg})$ in blue fox cubs in four experimental groups.

\begin{tabular}{|c|c|c|c|c|c|c|}
\hline & \multicolumn{2}{|c|}{ August } & \multicolumn{2}{|c|}{ September } & \multicolumn{2}{|c|}{ December } \\
\hline & $\begin{array}{c}\text { male } \\
\mathrm{N}=5\end{array}$ & $\begin{array}{l}\text { female } \\
\mathrm{N}=5\end{array}$ & $\begin{array}{c}\text { male } \\
\mathrm{N}=5\end{array}$ & $\begin{array}{c}\text { female } \\
\mathrm{N}=5\end{array}$ & $\begin{array}{c}\text { male } \\
\mathrm{N}=5\end{array}$ & $\begin{array}{l}\text { female } \\
\mathrm{N}=5\end{array}$ \\
\hline Pair-Handled & $5.5 \pm 1.5$ & $5.6 \pm 1.4$ & $8.6 \pm 1.0$ & $8.1 \pm 0.9$ & $11.3 \pm 1.5$ & $10.7 \pm 1.6$ \\
\hline Pair-Nonhandled & $4.7 \pm 0.5$ & $4.8 \pm 0.9$ & $8.4 \pm 0.7$ & $8.1 \pm 1.1$ & $12.1 \pm 1.6$ & $11.2 \pm 1.4$ \\
\hline Group-Handled & $5.8 \pm 1.3$ & $5.6 \pm 1.4$ & $8.9 \pm 0.8$ & $8.3 \pm 1.3$ & $12.2 \pm 1.1$ & $10.8 \pm 1.2$ \\
\hline Group-Nonhandled & $4.8 \pm 0.8$ & $4.7 \pm 0.8$ & $8.5 \pm 0.7$ & $7.7 \pm 0.5$ & $12.3 \pm 0.7$ & $10.9 \pm 0.7$ \\
\hline \multicolumn{7}{|l|}{ Significance levels } \\
\hline Sex & \multicolumn{2}{|c|}{ NS } & \multicolumn{2}{|c|}{0.068} & \multicolumn{2}{|c|}{0.013} \\
\hline Group size & \multicolumn{2}{|c|}{ NS } & \multicolumn{2}{|c|}{ NS } & \multirow{2}{*}{\multicolumn{2}{|c|}{ NS }} \\
\hline Early handling & \multicolumn{2}{|c|}{0.022} & \multicolumn{2}{|c|}{ NS } & & NS \\
\hline
\end{tabular}

Table 2. Mass of adrenals (mg), serum cortisol level (nmol/l) $2 \mathrm{~h}$ after adrenocorticotropic hormone administration and cortisol-creatinine ratio $\left(\mathrm{C}: \mathrm{C} \times 10^{-3}\right)$ in blue fox cubs in four experimental groups.

\begin{tabular}{|c|c|c|c|c|c|}
\hline & \multicolumn{2}{|c|}{ Adrenals } & \multicolumn{2}{|c|}{ Cortisol } & \multirow{2}{*}{$\begin{array}{l}\mathrm{C}: \mathrm{C} \\
\mathrm{N}=5\end{array}$} \\
\hline & $\begin{array}{c}\text { male } \\
\mathrm{N}=5\end{array}$ & $\begin{array}{c}\text { female } \\
\mathrm{N}=5\end{array}$ & $\begin{array}{c}\text { male } \\
\mathrm{N}=5\end{array}$ & $\begin{array}{c}\text { female } \\
\mathrm{N}=5\end{array}$ & \\
\hline Pair-Handled & $330 \pm 37$ & $333 \pm 40$ & $375 \pm 64$ & $423 \pm 71$ & $6.6 \pm 4.1$ \\
\hline Pair-Nonhandled & $296 \pm 29$ & $300 \pm 57$ & $296 \pm 49$ & $254 \pm 140$ & $5.9 \pm 1.3$ \\
\hline Group-Handled & $350 \pm 45$ & $352 \pm 36$ & $324 \pm 72$ & $350 \pm 45$ & $4.6 \pm 2.2$ \\
\hline Group-Nonhandled & $343 \pm 35$ & $302 \pm 40$ & $281 \pm 34$ & $283 \pm 45$ & $5.3 \pm 1.6$ \\
\hline \multicolumn{6}{|l|}{ Significance levels } \\
\hline Sex & \multicolumn{2}{|c|}{ NS } & \multicolumn{2}{|c|}{ NS } & NS \\
\hline Group size & \multicolumn{2}{|c|}{0.094} & \multicolumn{2}{|c|}{ NS } & NS \\
\hline Early handling & \multicolumn{2}{|c|}{0.022} & \multicolumn{2}{|c|}{0.000} & NS \\
\hline
\end{tabular}

sive early handling. Group size did not affect the serum cortisol level but a tendency for slightly heavier adrenals was found in six-animal groups (groups $\mathrm{GH}$ and $\mathrm{GNH}$ ).

Early handling had no significant effect on the percentage of animals coming to eat during any of the three feeding tests (Table 3 ). The effect of group size was significant for the feeding test behaviour only in late September when the percentage of animals coming to eat was lower in the housing units with six animals in each (groups GH and GNH) than in pair housed animals (groups $\mathrm{PH}$ and $\mathrm{PNH}$ ). Within each experimental group, the percentage of animals coming to eat during the feeding test increased with the advance of autumn.
Neither the group size nor the early handling had any effect on the daily activity level (Table 4). In general, the foxes were most active during the working hours (0800-1600). Furthermore, the total activity decreased from September to November, with a decreasing activity level noted during the morning and evening hours but not during the working hours.

Early handling did not affect the skin quality parameters (Table 5). The quality of the fur was slightly lower in the animals housed in groups of six than in the pair housed foxes. Furthermore, the females housed in groups GH and GNH had more bite scars than the females housed in pairs with their male sibling. 
Ahola, L. et al. Group housing and early handling in farmed blue foxes

Table 3. Percentage of animals eating during the feeding tests in blue fox cubs in four experimental groups.

\begin{tabular}{lcccc}
\hline & August & September & October & Sig. levels \\
\hline Pair-Handled & $20 \pm 45$ & $90 \pm 22$ & $100 \pm 0$ & 0.023 \\
Pair-Nonhandled & $40 \pm 42$ & $100 \pm 0$ & $90 \pm 22$ & 0.023 \\
Group-Handled & $10 \pm 22$ & $67 \pm 33$ & $87 \pm 22$ & 0.016 \\
Group-Nonhandled & $10 \pm 15$ & $53 \pm 32$ & $73 \pm 30$ & 0.009 \\
Significance levels & & & & \\
\multicolumn{1}{c}{ Group size } & NS & 0.007 & NS & \\
\multicolumn{1}{c}{ Early handling } & NS & NS & NS & \\
\hline
\end{tabular}

Table 4. Daily active time (\%) of blue fox cubs in four experimental groups during early hours (0000-0800), working hours (0800-1600) and evening hours (1600-0000). Significance levels measured with the Repeated Measures MANOVA: Handling NS, Group size NS, Month P = 0.001, Hours P = 0.000, Month $\times$ Hours 0.025. Other interactions NS.

\begin{tabular}{|c|c|c|c|c|c|c|}
\hline & \multicolumn{3}{|c|}{ September } & \multicolumn{3}{|c|}{ November } \\
\hline & $00-08$ & $08-16$ & $16-00$ & 00-08 & $08-16$ & $16-00$ \\
\hline Pair-Handled & $18 \pm 8$ & $41 \pm 13$ & $29 \pm 12$ & $13 \pm 3$ & $41 \pm 12$ & $20 \pm 10$ \\
\hline Pair-Nonhandled & $22 \pm 8$ & $41 \pm 8$ & $31 \pm 12$ & $13 \pm 5$ & $38 \pm 2$ & $17 \pm 5$ \\
\hline Group-Handled & $18 \pm 10$ & $36 \pm 11$ & $30 \pm 11$ & $12 \pm 1$ & $41 \pm 10$ & $23 \pm 7$ \\
\hline Group-Nonhandled & $15 \pm 4$ & $42 \pm 13$ & $30 \pm 60$ & $13 \pm 2$ & $39 \pm 5$ & $21 \pm 2$ \\
\hline
\end{tabular}

Table 5. Quality of the furs (score 1: poorest, 10: best) and incidence of bite scars in the skin (score 1: no bite scars, 7: extremely high number of scars) in blue fox cubs in four experimental groups.

\begin{tabular}{|c|c|c|c|c|}
\hline & \multicolumn{2}{|c|}{ Quality } & \multicolumn{2}{|c|}{ Scars } \\
\hline & $\begin{array}{c}\text { male } \\
\mathrm{N}=5\end{array}$ & $\begin{array}{c}\text { female } \\
\mathrm{N}=5\end{array}$ & $\begin{array}{c}\text { male } \\
\mathrm{N}=5\end{array}$ & $\begin{array}{c}\text { female } \\
\mathrm{N}=5\end{array}$ \\
\hline Pair-Handled & $5.4 \pm 1.3$ & $3.4 \pm 1.5$ & $3.3 \pm 2.1$ & $3.0 \pm 0.7$ \\
\hline Pair-Nonhandled & $4.8 \pm 1.6$ & $4.2 \pm 1.6$ & $3.5 \pm 1.0$ & $2.4 \pm 0.6$ \\
\hline Group-Handled & $3.7 \pm 0.4$ & $2.9 \pm 0.7$ & $3.3 \pm 0.9$ & $4.9 \pm 1.2$ \\
\hline Group-Nonhandled & $3.9 \pm 1.1$ & $2.5 \pm 0.4$ & $2.9 \pm 0.7$ & $4.2 \pm 1.1$ \\
\hline \multicolumn{5}{|l|}{ Significance levels } \\
\hline Group size & 0.052 & 0.052 & NS & 0.001 \\
\hline Early handling & NS & NS & NS & NS \\
\hline
\end{tabular}

\section{Discussion}

In the present study, two different aspects of housing environment of farmed blue fox cubs were assessed: the number of foxes in a housing unit, and the early handling of the cubs as a possible procedure for reducing the cubs' later fear towards humans. The results obtained resembled those previously found in pigs with regard to group size and space allowance (Randolph et al. 1981), that there was no interaction between these two factors. This indicates that group size and early handling of the animals affected the measured parameters in an independent manner. Therefore, the effects of early handling and 
Vol. 11 (2002): 25-35.

group size on the welfare of blue fox cubs will be discussed separately.

\section{Early handling}

The effect of early handling on production and welfare-related parameters of domestic animals has been evaluated in many studies (see Rushen et al. 1999). In some studies, weight gain has been significantly higher, although only for a limited period of time after the handling procedure, in animals handled gently in comparison to animals handled unpleasantly (pigs: Hemsworth et al. 1987, Hemsworth and Barnett 1991). In other studies, no effects on weight gain have been found (pigs: Pearce et al. 1989, Paterson and Pearce 1992; chicks: Leonard and Fairfull 1992). The same results have been detected when interpreting the effects of handling on the level of stress (pigs positive effect: Hemsworth et al. 1987, Barnett et al. 1994; pigs no effect: Hemsworth and Barnett 1991, Paterson and Pearce 1992). However, most of the experiments have succeeded in reducing fear reactions towards humans by handling procedures (pigs: Hemsworth et al. 1987, Pearce et al. 1989, Hemsworth and Barnett 1991, 1992, Paterson and Pearce 1992, Barnett et al. 1994; sheep: Hargreaves and Hutson 1990; silver foxes: Pedersen and Jeppesen 1990, Pedersen 1992, 1993).

The present results showed, that if any effect of early handling, performed before (0-3 weeks of age) and during the sensitive period of primary socialisation (3-6 and 3-9 weeks of age for unselected foxes and for foxes selected for domestic behaviour, respectively, Belyaev et al. 1985), on measured parameters was seen, this effect in blue foxes was positive only during the first weeks post-handling (higher body mass in August) and turned to be negative some months after handling (heavier adrenals, higher serum cortisol level after ACTH administration at pelting time). Furthermore, contrary to earlier studies where handling silver fox cubs six consecutive weeks pre-weaning reduced fearfulness of the cubs (Pedersen 1992), the present results re- vealed no effect of handling on a later fear reaction towards humans in blue foxes, as indicated by the results of the feeding tests. The feeding test, used in the present study, has been shown to measure fear of humans in farmed foxes (Rekilä et al. 1999). However, the earlier experiments using the feeding test have not included foxes housed in groups of six animals (Rekilä et al. 1997, 1999). The social environment may influence the responses of farm animals to their environment (see Nicol 1995) and individual stress responses to fear-eliciting situations (Grignard et al. 2000). Therefore, it could be argued that the present result of the feeding tests may actually not indicate only the level of fear of humans, but also the effects of group housing and of social tension within each housing unit on the behaviour of the foxes. Nonetheless, the percentage of animals that ate during the successive feeding tests increased which indicated habituation to the feeding test situation (Rekilä et al. 1997).

One explanation for the present findings may be that handling procedures, in general, have only relatively short-term effects, as proposed by Leonard and Fairfull (1992). Another reason for the detected negative effects of handling in the foxes in the present study might be that later routine handling, with its possibly negative nature, surmounted the positive effects of early handling (Hargreaves and Hutson 1990, Hemsworth and Barnett 1992, Pedersen 1994). Furthermore, one could also hypothesise that the animals who had received intense human handling during their sensitive period (Belyaev et al. 1985) might have felt yearning for human contact and, therefore, experienced long-term stress when it was missing later in their life.

\section{Group size}

In the present study, group size had no significant effects on the body mass or on the HPAaxis activity of the blue foxes, there was only a tendency for heavier adrenals in the foxes housed in six-animal groups. Furthermore, the 24-h ac- 
Ahola, L. et al. Group housing and early handling in farmed blue foxes

tivity was not affected by the group size, even though the activity during the dispersion time due either to the scarcity of resources (Chesemore 1975) or to the social tension (Christian 1970, Bekoff 1977) could be expected to increase more in larger groups than in pairs of foxes. One explanation for the lack of differences in the activity levels of the foxes may be that there were no restrictions in food availability and, therefore, there was no reason to avoid littermates, as has been reported earlier in wild arctic foxes (Frafjord 1992). However, the feeding test carried out in late September indicated that in six-animal groups there was some intra-litter tension that reduced the percentage of animals coming to eat during the test time. This was observed during the test when the most common observation was that all animals willing to come and eat were not permitted to enter the feeding site by the more dominant animals.

The effect of group size and social tension within the six-animal housing units was also seen in the incidence of bite scars: the skins from the female cubs housed in larger groups had significantly more bite scars than the skins of the cubs housed in pairs. This result emphasises that the females in particular were more likely to suffer from being housed in larger groups, i.e. being subdominant to male cubs (Wakely and Mallory 1988, Frafjord 1993). However, since there was no clear evidence of long-term stress in the foxes housed in six-animal groups, one could also suggest that the bite scars in the six-animal groups were perhaps accidentally inflicted during within-litter play behaviour.

\section{Conclusions}

The present results, combined with the earlier results by Ahola et al. (2000), suggest that, when housing farmed blue foxes in groups of up to six animals, space allocation may be a more important factor affecting the blue foxes' welfare than group size alone. Similar results have been reported earlier in heifers (Hindhede et al. 1996), pigs (Randolph et al. 1981) and foxes (Ahola et al. 1996). In the present study, the larger group size had a clear effect only on the large number of bite scars in the female blue fox cubs housed in six-animal groups. Furthermore, group size seemed to affect the behaviour of the foxes only during the time of natural dispersion, i.e. in late September, when intra-litter aggression was observed during the feeding test. On the other hand, early handling had only a transient positive effect on the performance of the foxes, later it had a negative impact on their stress profile.

It can be concluded that group housing, possibly even without intensive early handling of the animals, might be considered as an alternative way of housing farmed blue fox cubs. However, one has to bear in mind that the present conclusions may not be applicable, as such, to different group sizes and groups with different animal compositions (e.g. different numbers of males and females, unrelated animals).

Acknowledgements. This study was supported by The Research Council for the Environment and Natural Resources of the Academy of Finland and by the Finnish Fur Breeders Association (FFBA) through a joint project between FFBA and the Finnish Society for the Protection of Animals. We are grateful to Mrs. Maija Miskala for her skilful assistance during the field experiments. 
Ahola, L., Harri, M., Kasanen, S., Mononen, J. \& Pyykönen, T. 2000. Effects of group housing in an enlarged cage system on growth, bite wounds and adrenal cortex function in farmed blue foxes (Alopex lagopus). Animal Welfare 9: 403-412.

Ahola, L., Harri, M., Mononen, J. \& Rekilä, T. 1996. Family housing of blue and silver foxes in a row cage system. In: Frindt, A. \& Brzozowski, M. (eds.). Applied Science Reports 29. Progress in fur animal science. Proceedings from the Sixth International Scientific Congress in Fur Animal Production, 21-23 August 1996, Warsaw, Poland. Polish Society of Animal Production, Warsaw. p.71-76.

Appleby, M.C. \& Waran, N.K. 1997. Physical conditions. In: Appleby, M.C. \& Hughes, B.O. (eds.). Animal Welfare. CAB International, University Press, Cambridge, UK. p. 177-190.

Barnett, J.L., Hemsworth, P.H., Hennesy, D.P., McCallum, T.H. \& Newman, E.A. 1994. The effects of modifying the amount of human contact on behavioural, physiological and production responses of laying hens. Applied Animal Behaviour Science 41: 87-100.

Bekoff, M. 1977. Mammalian dispersal and the ontogeny of individual behavioral phenotypes. American Naturalist 111: 715-732.

Belyaev, D.K., Plyusnina, I.Z. \& Trut, L.N. 1985. Domestication in the silver fox (Vulpes fulvus Desm): Changes in physiological boundaries of the sensitive period of primary socialization. Applied Animal Behaviour Science 13: 359-370.

Chesemore, D.L. 1975. Ecology of the arctic fox (Alopex lagopus) in North America - a review. In: Fox, M.W. (ed.). The wild canids. Their systematics, behavioral ecology and evolution. Robert E. Krieger Publishing Company, Inc., Malabar, Florida. p. 143-163.

Christian, J.J. 1970. Social subordination, population density, and mammalian evolution. Science 168: 8490.

Frafjord, K. 1992. Denning behaviour and activity of arctic fox Alopex lagopus pups: Implications of food availability. Polar Biology 12: 707-712.

Frafjord, K. 1993. Agonistic behaviour and dominance relations of captive arctic foxes (Alopex lagopus) in Svalbard. Behavioural Processes 29: 239-252.

Fraser, A.F. \& Broom, D.M. 1990. Farm animal behaviour and welfare. $3^{\text {rd }}$ edition. Baillière Tindall, London, UK. 437 p.

Grignard, L., Boissy, A., Boivin, X., Garel, J.P. \& Le Neindre, P. 2000. The social environment influences the behavioural responses of beef cattle to handling. Applied Animal Behaviour Science 68: 1-11.

Hargreaves, A.L. \& Hutson, G.D. 1990. The effect of gentling on heart rate, flight distance and aversion of sheep to a handling procedure. Applied Animal Behaviour Science 26: 243-252.

Harri, M., Mononen, J., Rekilä, T., Korhonen, H. \& Niemelä, P. 1998. Effects of top nest box on growth, fur quality and behaviour of blue foxes (Alopex lago- pus) during their growing season. Acta Agriculturae Scandinavica, Section A, Animal Science 48: 184191.

Hemsworth, P.H. \& Barnett, J.L. 1991. The effects of aversively handling pigs, either individually or in groups, on their behaviour, growth and corticosteroids. Applied Animal Behaviour Science 30: 61-72.

Hemsworth, P.H. \& Barnett, J.L. 1992. The effects of early contact with humans on the subsequent level of fear of humans in pigs. Applied Animal Behaviour Science 35: 83-90.

Hemsworth, P.H., Barnett, J.L. \& Hansen, C. 1987. The influence of inconsistent handling by humans on the behaviour, growth and corticostreroids of young pigs. Applied Animal Behaviour Science 17: 245-252.

Hindhede, J., Sorensen, J.T., Jensen, M.B. \& Krohn, C.C. 1996. Effect of space allowance, access to bedding, and flock size in slatted floor systems on the production and health of daily heifers. Acta Agriculturae Scandinavica, Section A, Animal Science 46: 46-53.

Korhonen, H. \& Alasuutari, S. 1994. Social relationships and reproductive performance in group-living arctic blue foxes. Agricultural Science in Finland 3: 49-58.

Korhonen, H. \& Alasuutari, S. 1995. Dominance relations in captive groups of adult and juvenile arctic blue foxes (Alopex lagopus). Polar Biology 15: 353-358.

Korhonen, H. \& Niemelä, P. 1994. Comparison of production results between blue foxes housed with and without platforms. Agricultural Science in Finland 4: 351-361.

Korhonen, H. \& Niemelä, P. 2000. Enrichment value of wooden blocks for farmed blue foxes (Alopex lagopus). Animal Welfare 9: 177-191.

Korhonen, H., Niemelä, P., Jauhiainen, L. \& Tupasela, T. 2000. Effects of space allowance and earthen floor on welfare-related physiological and behavioural responses in male blue foxes. Physiology \& Behavior 69: $571-580$.

Lasley, B.L. \& Kirkpatric, J.F. 1991. Monitoring ovarian function in captive and free-ranging wildlife by means of urinary and fecal steroids. Journal of Zoo and Wildlife Medicine 22: 23-31.

Leonard, M.L. \& Fairfull, R.W. 1992. Effect of early handling on growth, mortality and feed efficiency in White Leghorns. Applied Animal Behaviour Science 34: 121-128.

Martin, P. \& Bateson, P. 1993. Measuring behaviour, an introductory guide. 2nd ed. University Press, Cambridge, UK. $222 \mathrm{p}$.

Mendl, M. \& Newberry, R.C. 1997. Social conditions. In: Appleby, M.C. \& Hughes B.O. (eds.). Animal Welfare. CAB International, University Press, Cambridge, UK. p. 191-203.

Mononen, J. 1996. Resting platforms and nest boxes for farmed blue foxes (Alopex lagopus) and silver foxes (Vulpes vulpes). The extent of use, reasons for use and welfare effects. Kuopio University Publications C. Natural and Environmental Sciences 52.62 p. 
Ahola, L. et al. Group housing and early handling in farmed blue foxes

Mononen, J., Harri, M., Sepponen, J., Korhonen, H., Rekilä, T. \& Ahola, L. 1999. A top box and a floor box as breeding nest boxes in farmed blue foxes (Alopex lagopus): Reproductive performance, use of the boxes and cub carrying. Acta Agriculturae Scandinavica, Section A, Animal Science 49: 206-210.

Nicol, C.J. 1995. The social transmission of information and behaviour. Applied Animal Behaviour Science 44: 79-98.

Novak, M.A. \& Drewsen, K.H. 1989. Enriching the lives of captive primates. In: Segal, E.F. (ed.). Housing, care and psychological wellbeing of captive and laboratory primates. Park Ridge, NJ: Noyes Publications. p. 162-164.

Paterson, A.M. \& Pearce, G.P. 1992. Growth, response to humans and corticosteroids in male pigs housed individually and subjected to pleasant, unpleasant or minimal handling during rearing. Applied Animal Behaviour Science 34: 315-328.

Pearce, G.P., Paterson, A.M. \& Pearce, A.N. 1989. The influence of pleasant and unpleasant handling and the provision of toys on the growth and behaviour of male pigs. Applied Animal Behaviour Science 23: 2737.

Pedersen, V. 1992. Handling of silver foxes at different ages pre-weaning and post-weaning and effects on later behaviour and stress-sensitivity. Norwegian Journal of Agricultural Sciences, Suppl. No. 9: 529535.

Pedersen, V. 1993. Effects of different post-weaning handling procedures on the later behaviour of silver foxes. Applied Animal Behaviour Science 37: 239-250.

Pedersen, V. 1994. Long-term effects of different handling procedures on behavioural, physiological, and production-related parameters in silver foxes. Applied Animal Behaviour Science 40: 285-296.
Pedersen, V. \& Jeppesen, L.L. 1990. Effects of early handling on later behaviour and stress responses in the silver fox (Vulpes vulpes). Applied Animal Behaviour Science 26: 383-393.

Pedersen, V. \& Jeppesen, L.L. 1993. Daytime use of various types of whole-year shelters in farmed silver foxes (Vulpes vulpes) and blue foxes (Alopex lagopus). Applied Animal Behaviour Science 36: 259-273.

Pedersen, V. \& Jeppesen, L.L. 1998. Different cage sizes and effects on behaviour and physiology in farmed silver and blue foxes. Scientifur 22: 13-22.

Randolph, J.H., Cromwell, G.L., Stahly, T.S. \& Kratzer, D.D. 1981. Effects of group size and space allowance on performance and behavior of swine. Journal of Animal Science 53: 922-927.

Rekilä, T., Harri, M. \& Ahola, L. 1997. Validation of the feeding test as an index of fear in farmed blue (Alopex lagopus) and silver foxes (Vulpes vulpes). Physiology \& Behavior 62: 805-810.

Rekilä, T., Harri, M., Jalkanen, L. \& Mononen, J. 1999. Relationship between hyponeophagia and adrenal cortex function in farmed foxes. Physiology \& Behavior 65: 779-783.

Rushen, J., Taylor, A.A. \& de Pasillé, A.M. 1999. Domestic animals' fear of humans and its effect on their welfare. Applied Animal Behaviour Science 65: 285303.

Terlouw, E.M.C., Schouten, W.G.P. \& Ladewig, J. 1997. Physiology. In: Appleby, M.C. \& Hughes B.O. (eds.). Animal Welfare. CAB International, University Press, Cambridge, UK. p. 143-158.

Wakely, L.G. \& Mallory, F.F. 1988. Hierarchical development, agonistic behaviours, and growth rates in captive arctic fox. Canadian Journal of Zoology 66: 16721678. 
Vol. 11 (2002): 25-35.

\title{
SELOSTUS
}

\section{Ryhmäkoon ja varhaisen käsittelyn vaikutus tarhattujen sinikettujen hyvinvointiin}

\author{
Leena Ahola, Mikko Harri, Jaakko Mononen, Teija Pyykönen ja Sari Kasanen \\ Kuopion yliopisto
}

Tarhattuja sinikettuja kasvatetaan vieroituksen jälkeen yleisimmin uros-naaraspareittain perinteisissä kettuhäkeissä. Kritiikki tätä kasvatustapaa kohtaan ja yleinen kiinnostus tuotantoeläinten hyvinvointiin on kuitenkin lisännyt tarvetta etsiä vaihtoehtoisia kasvatusmuotoja tarhattaville turkiseläimille. Tässä työssä selvitettiin sisarusten läsnäolon (sosiaalinen rikaste) ja varhaisen käsittelyn (eläimen pelokkuuden vähentäminen ihmisen läheisyyteen tottumisen seurauksena) vaikutusta tarhattujen sinikettupentujen hyvinvointiin. Saadut tulokset osoittivat, että sinikettujen varhaisella käsittelyllä oli vain lyhytkestoinen positiivinen vaikutus, joka näkyi kasvun parantumisena kasvukauden alussa. Myöhemmin syksyllä varhaista käsittelyä saaneiden kettujen lisämunuaisen aktiivi- suus oli kuitenkin korkeampaa, eli käsitellyt ketut näyttivät kokeneen pitkäkestoista stressiä enemmän kuin käsittelemättömät ketut. Ryhmäkoko (uros-naaraspari tai ryhmä, jossa kolme urosta ja kolme naarasta) ei vaikuttanut mitattuihin fysiologisiin hyvinvointiparametreihin, vaikka ryhmänsisäistä aggressiivisuutta havaittiinkin syyskuussa suoritettujen ruokintatestien yhteydessä. Lisäksi kuuden ketun ryhmässä kasvaneilla naarasketuilla oli nahassaan enemmän puremajälkiä kuin urosveljensä kanssa kahden kasvaneilla naarasketuilla. Yhteenvetona tuloksista voidaan todeta, että sinikettupentujen kasvattaminen sosiaalista virikettä enemmän antavissa penturyhmissä voisi olla yksi vaihtoehtoinen kasvatusmuoto tarhatuille siniketuille. 